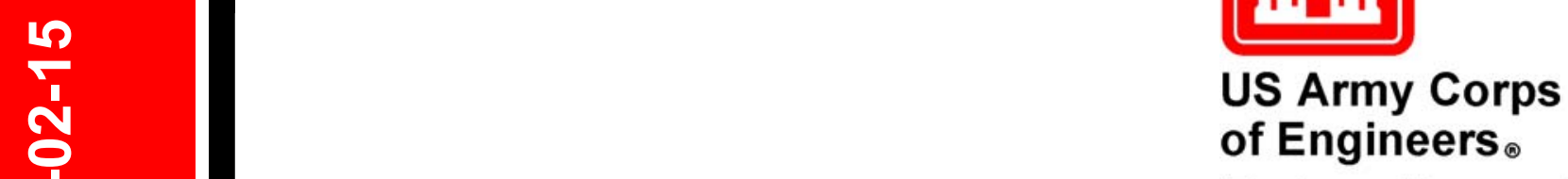

Engineer Research and Development Center

\title{
Natural Gas-Electric Hybrid Cooling System for Army Facilities - A Decision Tool
}

Chang W. Sohn and Jorge L. Alvarado July 2002

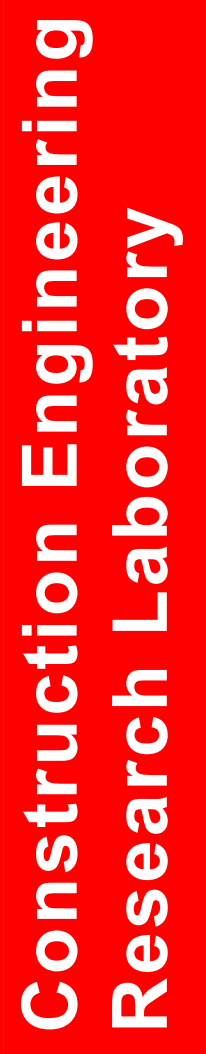




\section{Foreword}

This study was conducted for the Directorate of Military Programs (CEMP), Headquarters, U.S. Army Corps of Engineers (HQUSACE), under Project 4A262784AT45, "Energy and Energy Conservation"; Task CF; Work Unit X60 "Hybrid Cooling Technologies."

The work was performed by the Energy Branch (CF-E) of the Facilities Division (CF), Construction Engineering Research Laboratory (CERL). The Principal Investigator was Dr. Chang W. Sohn. Dr. Thomas Hartranft is Chief, CF-E; and L. Michael Golish is Chief, CF. The technical editor was Linda L. Wheatley, Information Technology Laboratory. The associated Technical Director was Gary W. Schanche, CV-T. The Director of CERL is Dr. Alan W. Moore.

CERL is an element of the U.S. Army Engineer Research and Development Center (ERDC), U.S. Army Corps of Engineers. The Commander and Executive Director of ERDC is COL John W. Morris, III, EN, and the Director is Dr. James R. Houston.

DISCLAIMER: The contents of this report are not to be used for advertising, publication, or promotional purposes. Citation of trade names does not constitute an official endorsement or approval of the use of such commercial products. All product names and trademarks cited are the property of their respective owners. The findings of this report are not to be construed as an official Department of the Army position unless so designated by other authorized documents.

DESTROY THIS REPORT WHEN IT IS NO LONGER NEEDED. DO NOT RETURN IT TO THE ORIGINATOR. 


\section{Contents}

Foreword

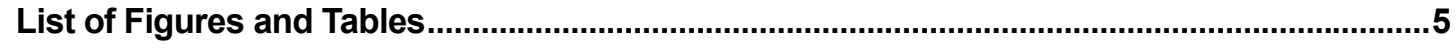

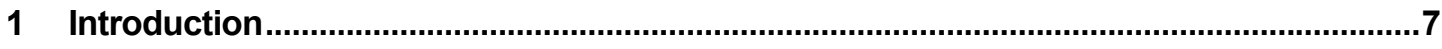

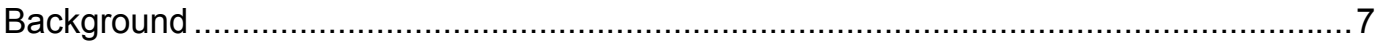

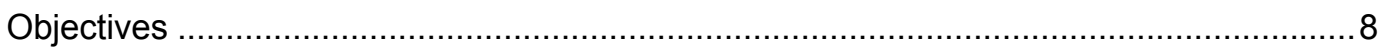

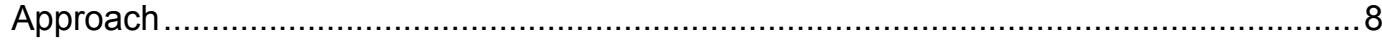

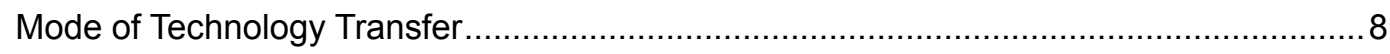

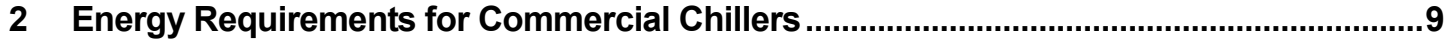

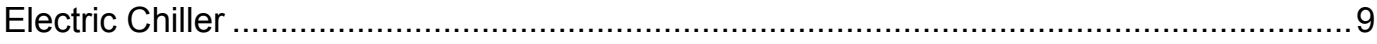

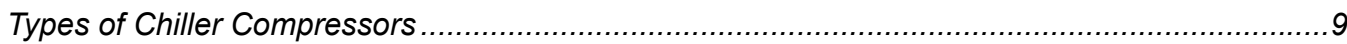

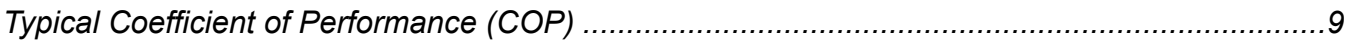

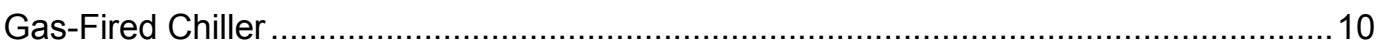

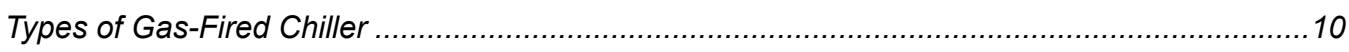

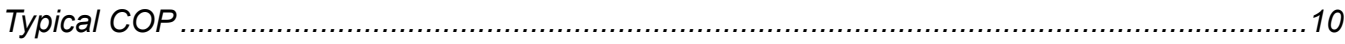

Results From Gas Cooling Field Demonstration ......................................................... 11

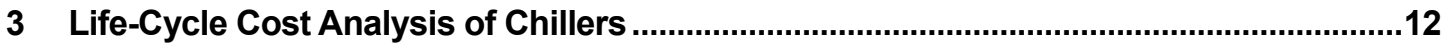

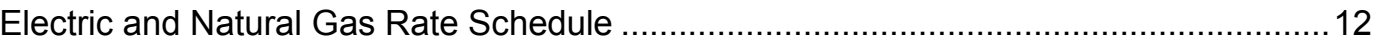

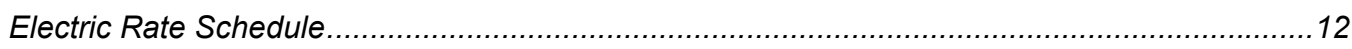

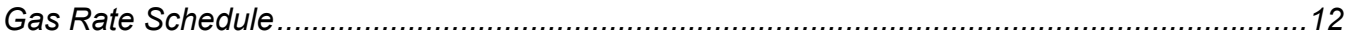

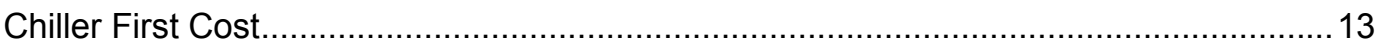

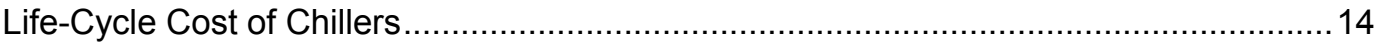

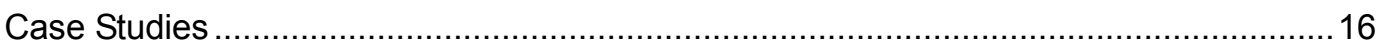

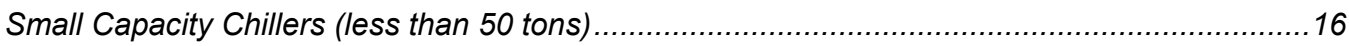

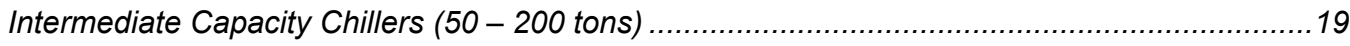

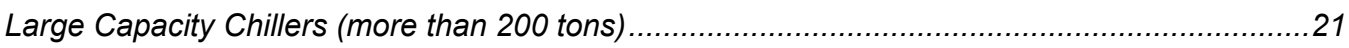

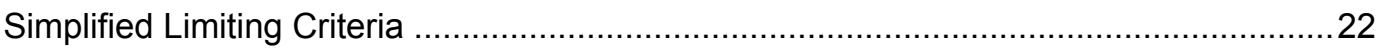

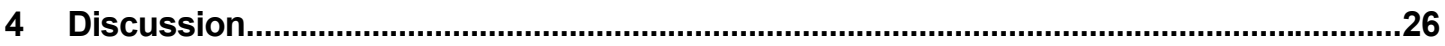

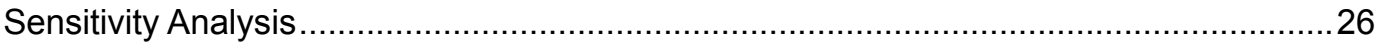

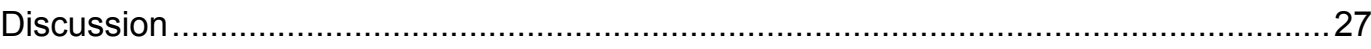

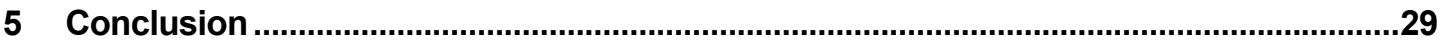

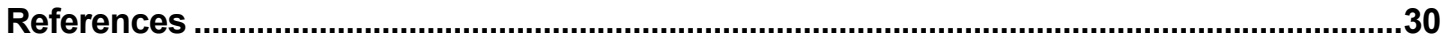




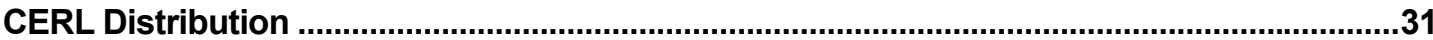

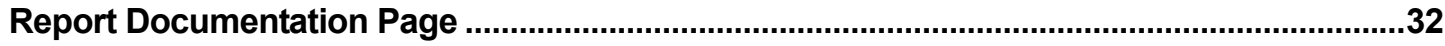




\section{List of Figures and Tables}

\section{Figures}

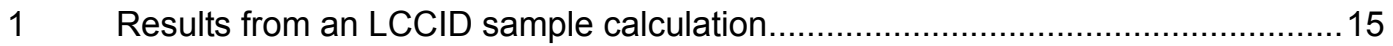

2 LCCID input/Excel ${ }^{\circledR}$ spreadsheet file for electric chiller (Fort Stewart) .................. 17

3 LCCID input/Excel ${ }^{\circledR}$ spreadsheet file for gas-engine chiller (Fort Stewart) ............ 17

$4 \quad$ LCCID results for Fort Stewart, GA (40 ton)................................................. 18

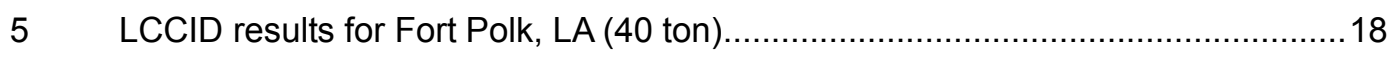

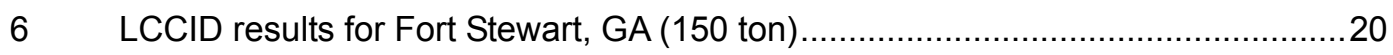

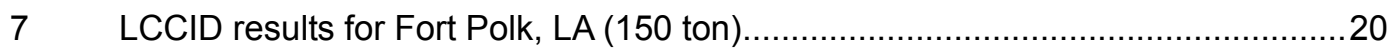

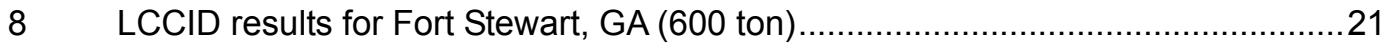

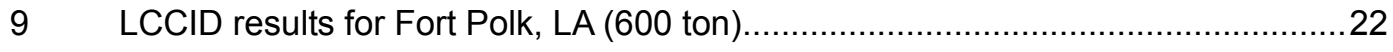

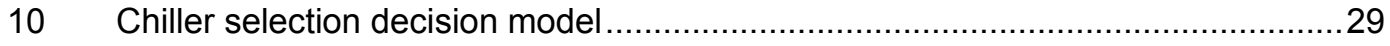

\section{Tables}

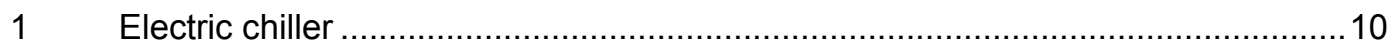

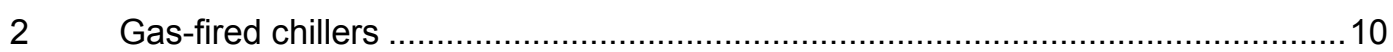

$3 \quad$ Summary of gas chiller field performance ........................................................ 11

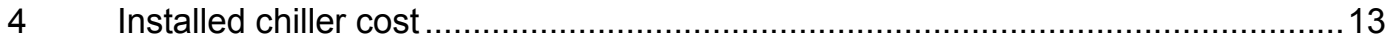

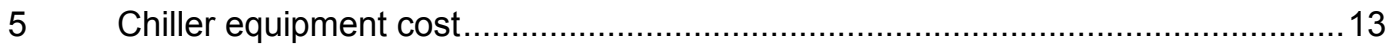

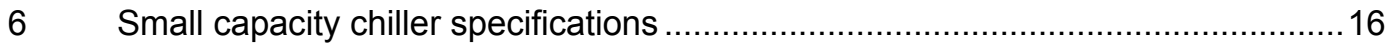

$7 \quad$ Electric and gas rates for Fort Stewart and Fort Polk ...................................... 16

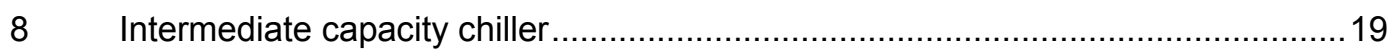

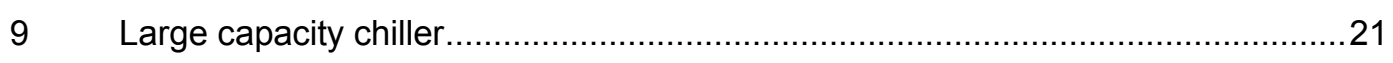

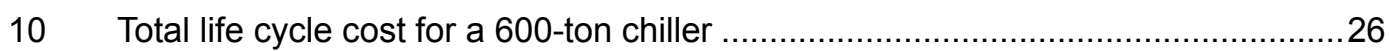





\section{Introduction}

\section{Background}

For a typical Army installation, space cooling is the major contributor in the electrical energy consumption and the peak electrical demand. For example, a detailed study of end use of electricity at Fort Hood, TX, showed that cooling was responsible for 54 percent of the total peak demand of electricity and 33 percent of the total electricity consumed (Akbari and Konopacki 1995). In Fiscal Year (FY) 2000 (October 1999 - September 2000), the annual electrical bill for Fort Hood was $\$ 14.2$ million with total electrical energy consumption of $278,642,877 \mathrm{kWh}$ and the annual peak demand of $52,334 \mathrm{~kW}$. Note that the annual peak demand is established in the summer months during utility on-peak periods when space cooling needs are highest.

As a means of reducing the electrical energy requirement for space cooling operation, natural gas powered cooling systems have been introduced in the market in the 1990s. During FY93-95, the U.S. Congress funded $\$ 25$ million to demonstrate gas cooling systems in Department of Defense (DoD) installations. By the end of 1998, natural gas cooling systems were in operation at more than 40 DoD installations, including more than a dozen Army installations (Sohn 1997). The Army applications ranged from a small capacity (25 ton) gas-engine chiller for a daycare center, to mid-capacity (150 ton) units for cooling barracks, to large capacity (700 ton) units for central energy plants.

The economical benefit of electric/natural gas hybrid cooling systems was widely promoted in the air-conditioning industry during the 1990s. Nowakowski and Gramlich (1999) reviewed the development of hybrid natural gas/electric cooling, and Meckler (1999) discussed hybrid chiller selection strategies under the deregulating electrical market. Liegois (2000) analyzed the economics of chiller selection on a variety of fuel sources.

Natural gas cooling systems offer savings in cooling cost by reducing on-peak electrical demand and, at certain sites, reducing the cost of energy by using natural gas instead of electricity. The natural gas cooling systems and natural gas/electric hybrid cooling systems are still under evaluation by the industry as a cost-effective alternate to the electric-only cooling systems. Economic feasibility of these hybrid 
cooling systems depends on the cost differential between electricity and natural gas at a given location. A compilation of electrical and natural gas rate schedules in major Army installations was reported in Feickert and Sohn (2000).

\section{Objectives}

The objectives of this research were to: (1) study the field performance of natural gas cooling systems, (2) analyze life-cycle cost (LCC) feasibility of hybrid cooling systems in typical Army applications, and (3) develop criteria to be used by Army engineers for selecting hybrid cooling systems.

\section{Approach}

The cost and energy efficiency of electric chillers in the current market were studied to establish a baseline for the LCC analysis. Feedback from the field operators of the natural gas cooling systems was collected and analyzed. The fuel cost savings by the natural gas engine driven chillers were estimated. Typical Army implementation was categorized in three types - small, intermediate, and large capacity units. LCC calculations were performed for these categories. A solution model and supporting tools were developed.

\section{Mode of Technology Transfer}

Army engineers can use the information in this report to select cost-effective chillers for new construction and retrofit projects. The information in this report will be presented as a technical paper to the U.S. Army Corps of Engineers (USACE) Electrical and Mechanical Training Conference. It will also be presented to the Corps of Engineers National Energy Team annual meeting. 


\section{Energy Requirements for Commercial Chillers}

\section{Electric Chiller}

Electric chillers are vapor compression systems using electric motors to drive a compressor unit. Several types of electric chillers are available on the commercial market. These chillers are designed and selected based on cooling capacity and applications.

\section{Types of Chiller Compressors}

Centrifugal compressors exchange angular momentum continuously with the refrigerant and have greater volumetric capacities than other compressors by using some type of turbine or propeller. They also can produce high-pressure ratios.

Screw compressors are either single or twin-screw compressors. Single and twinscrew compressors make use of helically grooved rotors to compress the refrigerant. They are designed to perform at low or high compression ratios.

Reciprocating compressors consist of single acting pistons to compress the refrigerant. These compressors require lubrication for the moving parts.

Rotary compressors consist of rolling pistons and fixed vanes, or rotary vanes, which compress the refrigerant. Rotary compressors have a high volumetric efficiency.

Scroll compressors are orbital motion, positive-displacement machines that compress a refrigerant with two spiral-shaped scroll members. Capacities range from 1 to 15 tons of refrigeration.

\section{Typical Coefficient of Performance (COP)}

Table 1 shows typical COPs for the electric chillers listed above. 
Table 1. Electric chiller.

\begin{tabular}{|l|c|c|c|}
\hline Chiller Type & $\begin{array}{c}\text { Capacity Range } \\
\text { (tons) }\end{array}$ & COP Range & $\begin{array}{c}\text { Efficiency } \\
\text { (kW/ton) }\end{array}$ \\
\hline Centrifugal & $150-7000$ & $5.5-7.4$ & $0.48-0.64$ \\
\hline Screw & $40-1100$ & $2.7-5.8$ & $0.61-1.30$ \\
\hline Reciprocating & $2-450$ & $1.9-4.3$ & $0.82-1.85$ \\
\hline Rotary & $1-3$ & $2.6-2.8$ & $1.26-1.35$ \\
\hline Scroll & $10-60$ & $3.0-4.2$ & $0.84-1.17$ \\
\hline
\end{tabular}

\section{Gas-Fired Chiller}

Gas-fired chillers are either vapor compression systems using a gas engine to drive a compressor unit or an absorption system driven by heat. Several types of gasfired chillers are available on the commercial market. These chillers are designed and selected based on cooling needs and the long-term cost benefit.

\section{Types of Gas-Fired Chiller}

A gas engine-driven chiller is a conventional vapor compression system powered by a natural gas engine. Natural gas powered chillers have certain benefits including variable speed, high part-load efficiency and reduced total operating cost if the fuel cost structure is favorable to natural gas. Gas engine-driven chillers also consist of reciprocating, screw, or centrifugal chillers.

Absorption chillers are refrigeration units that provide cooling by regenerating a refrigerant with heat. Instead of having a compressor unit, an absorption chiller has an absorber and generator that accomplish the same task. Absorption chillers have the advantage of using economically available sources of heat for the regeneration process.

\section{Typical COP}

Table 2 shows typical COPs for the gas-fired chillers described above.

Table 2. Gas-fired chillers.

\begin{tabular}{|l|c|c|}
\hline Chiller Type & $\begin{array}{c}\text { Capacity Range } \\
\text { (tons) }\end{array}$ & COP* Range \\
\hline Gas Engine-Driven Chiller & $3-6000$ & $0.8-2.0$ \\
\hline Absorption Chiller & $3-1700$ & $0.7-1.4$ \\
\hline * COP is defined as a ratio of useful refrigeration effect and heat \\
input to generate the same refrigeration effect. \\
\hline
\end{tabular}




\section{Results From Gas Cooling Field Demonstration}

Performance of a few gas-engine driven chillers was measured during field demonstrations (Brown 1998). Table 3 summarizes the results.

Significant cooling cost savings were reported (Brown 1998). The gas engines presented additional maintenance requirements. Service contracts to maintain these gas cooling systems were universally recommended.

Table 3. Summary of gas chiller field performance.

\begin{tabular}{|l|l|c|c|c|r|}
\hline Site & Chiller type & Capacity & \multicolumn{3}{|c|}{ COP } \\
\hline Utah ANG & Reciprocal air-cooled & 55 ton & 0.98 (full) & $1.04(75 \%)$ & $0.95(50 \%)$ \\
\hline $\begin{array}{l}\text { Youngstown-Warren } \\
\text { ARS }\end{array}$ & Screw water-cooled & 140 ton & 1.34 (full) & $1.62(67 \%)$ & $1.7(57 \%)$ \\
\hline Davis-Monthan AFB & $\begin{array}{l}\text { Centrifugal water-cooled } \\
\text { (Unit \#1) }\end{array}$ & 650 ton & 2.08 (avg) & & \\
\hline Davis-Monthan AFB & $\begin{array}{l}\text { Centrifugal water-cooled } \\
\text { (Unit\#2) }\end{array}$ & 650 ton & 1.68 (avg) & & \\
\hline
\end{tabular}




\section{Life-Cycle Cost Analysis of Chillers}

\section{Electric and Natural Gas Rate Schedule}

\section{Electric Rate Schedule}

Numerous pricing structures exist in the continental United States (CONUS). The pricing is typically driven by two primary factors: the total energy (in kilowatt hours) consumed, and the "demand" (in kilowatts). Certain ancillary parameters, however, might modify the total functionality, such as ratchets, fuel cost, etc. Most electric rate structures can be categorized as one of the following three types: (1) Energy Plus Straight Demand, (2) Energy Plus Multi-tiered Demand, and (3) Real Time Pricing (RTP).

Energy Plus Straight Demand: This rate structure consist of two parts - one for the energy charge based on the total kilowatt hours consumed during the billing period, and the demand charge based on the billing demand in kilowatts during the same period. Utility companies may offer two rates for each part — one for on-peak use and the other for off-peak use.

Energy Plus Multi-Tiered Demand: This rate structure is similar to the Energy Plus Straight Demand. The major difference between the two structures is the way in which demand charge is calculated. Utility companies offer different ways to charge for demand charge, but the simplest form is to charge fixed cost for a set amount of demand (kilowatts) for a given period.

Real Time Pricing: This rate structure is based on what the market can sustain. The customer is notified in advance of what the hourly rate is going to be during the proceeding time period (usually 24 hours).

\section{Gas Rate Schedule}

Gas has many of the same pricing parameters that characterize the electrical industry. On the other hand, gas rates also take into account transportation, pumping, and storage costs. Gas rate are marketed and sold in units of cubic feet, therms, or British thermal units (Btus). A comprehensive discussion of 
electrical and natural gas rate structures for major CONUS Army installations is presented in Feickert and Sohn (2000).

\section{Chiller First Cost}

Chiller first cost mainly consists of equipment and installation costs. Chiller first cost depends on the type of condenser unit. First cost differs significantly between electric and gas-fired chillers. Table 4 shows the rough cost of installed chillers, and Table 5 shows the range of chiller equipment cost based on the capacity and type of the unit.

Further information on chiller first cost can be found in Sohn (1997) and the Electric Power Research Institute (EPRI) Electric Chiller Handbook (EPRI 1998).

Table 4. Installed chiller cost.

\begin{tabular}{|l|c|c|c|c|}
\hline Type & Size (Tons) & $\begin{array}{c}\text { Compressor } \\
\text { Type }\end{array}$ & $\begin{array}{c}\text { Efficiency } \\
\text { (Kw/Ton or COP) }\end{array}$ & $\begin{array}{c}\text { First Cost } \\
\text { (\$/Ton) }\end{array}$ \\
\hline Electric & 40 & Scroll & $1.1 \mathrm{~kW} /$ Ton & 1,300 \\
\hline Gas-Engine & 40 & Reciprocating & COP $=0.95$ & 2,000 \\
\hline Electric & 150 & Screw & $0.64 \mathrm{~kW} / T o n$ & 1,000 \\
\hline Gas-Engine & 150 & Screw & COP $=1.5$ & 1,500 \\
\hline Electric & 600 & Centrifugal & $0.56 \mathrm{~kW} /$ Ton & 800 \\
\hline Gas-Engine & 600 & Screw & COP $=1.92$ & 1,000 \\
\hline
\end{tabular}

Table 5. Chiller equipment cost.

\begin{tabular}{|l|c|c|}
\hline Chiller Type & Capacity Range (tons) & \$/ton \\
\hline \multicolumn{3}{|l|}{ Electric Chiller } \\
\hline Centrifugal & $150-7000$ & $210-475$ \\
\hline Screw & $40-1100$ & $160-675$ \\
\hline Reciprocating & $2-450$ & $200-2500$ \\
\hline Rotary & $1-3$ & $500-560$ \\
\hline Scroll & $10-60$ & $425-750$ \\
\hline Gas-Fired Chiller & $3-6000$ & $500-2300$ \\
\hline Gas Engine-Driven Chiller & $3-1700$ & $200-4500$ \\
\hline Absorption Chiller &
\end{tabular}




\section{Life-Cycle Cost of Chillers}

To select the best chiller for a given application, LCC analysis should be performed. The Life Cycle Cost In Design (LCCID) is an official software tool for life-cycle economic analysis developed by USACE. LCCID allows quick computation of LCC. It is available free of charge to all DoD components (for more information, see the ERDC/CERL web page on Products/Capabilities at:

http://www.cecer.army.mil/td/tips/index.cfm.)

LCCID needs the following information from the user:

General Information

- Project Title

- Project Number

- Fiscal Year (Current FY)

- Installation Name

- Design Feature

- Name of Analyst

- Date of Study (Current date)

- Midpoint of Construction (in case of chiller, midpoint date of installation)

- Beneficial Occupancy Date (First day of operation)

- Economic Life of Building (Period of study, i.e., 20 years, etc.)

Specific Information

- Census Region (Location, i.e., State)

- Fuel Cost (\$/kWh and $\$ /$ therm)

- Construction/Acquisition Cost (Total equipment and installation cost)

- Annual Energy Cost (kWh consumed in a year, annual demand cost, and Btus consumed in a year)

- Annual Maintenance Cost

- Major Repair and Replacement (frequency may vary)

To facilitate calculation of the required specific information, an Excel ${ }^{\circledR}$ spreadsheet/LCCID input file was used in this report.

The Exce $\mathrm{I}^{\circledR}$ spreadsheet/LCCID Input file requires the following information:

- Capacity of unit (tons)

- Number of hours in operation per year

- Efficiency of electric chiller (kW/ton) or COP of gas-fired chiller (Btu-refrigeration/Btu-heat input)

- Installed equipment cost $(\$ /$ ton $)$

- Percentage of operation hours during on-peak (electric chiller only)

- On-peak electricity energy charge $(\$ / \mathrm{kWh})$

- Off-peak electricity energy charge $(\$ / \mathrm{kWh})$

- On-peak electricity demand charge $(\$ / \mathrm{kW})$

- Study life (years) 
The Excel ${ }^{\circledR}$ spreadsheet/LCCID input file generates the following information to be keyed into LCCID:

- Weighted-average electricity energy cost $(\$ / \mathrm{kWh})$

- Total installed equipment cost $(\$)$

- Total electric energy consumed per year (MWh)

- Electricity demand cost per year $(\$)$

- Annual maintenance cost (\$)

- Gas energy consumed per year (MBtu, for gas engine only)

- Replacement cost (for gas engine only, incurred at a specified period of time)

Once all the necessary information has been input to LCCID, it determines total LCC, savings to investment ratio (SIR), and discounted payback period (DPP) for two or more alternatives. Figure 1 shows the results of an LCCID calculation.

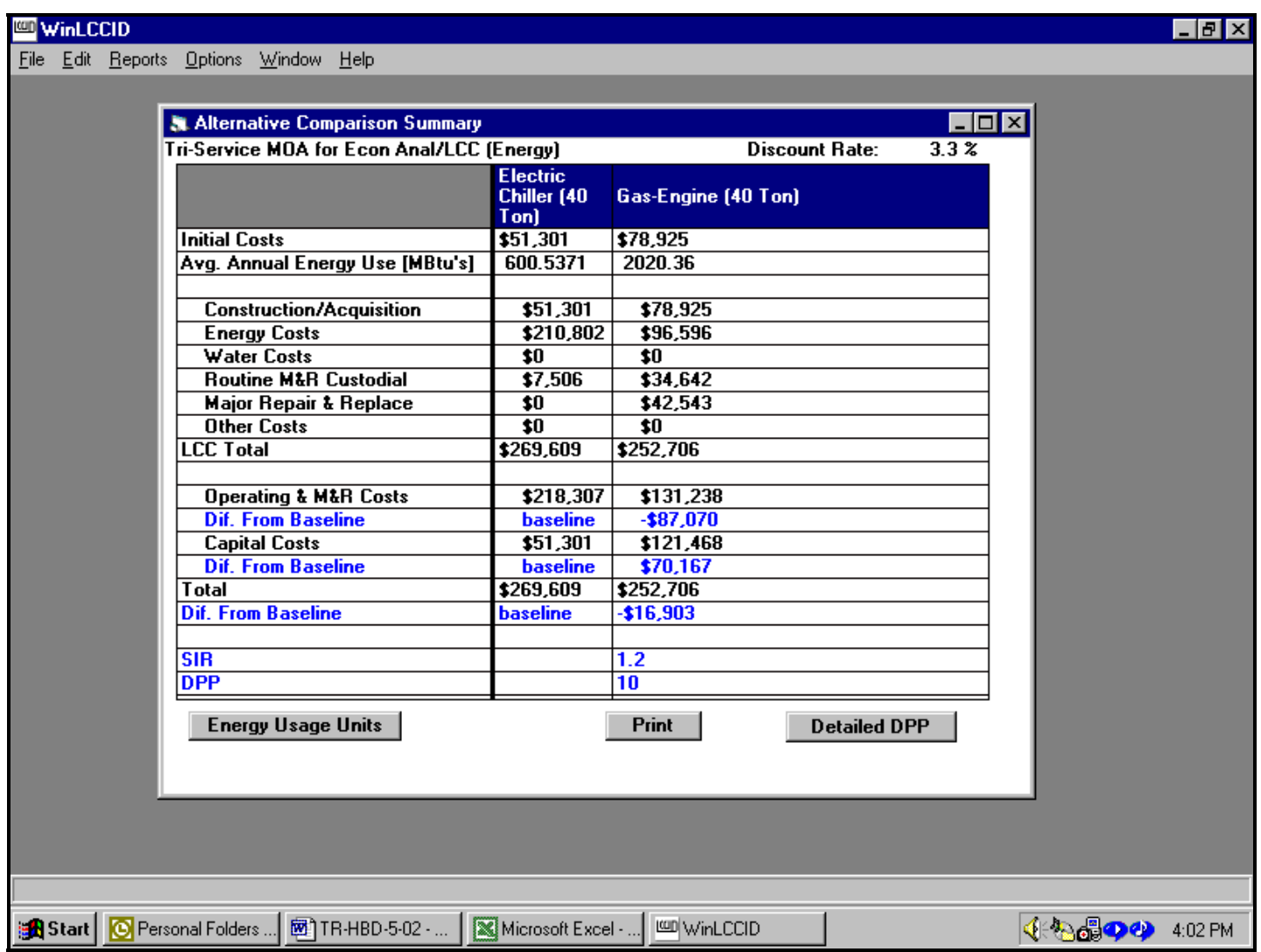

Figure 1. Results from an LCCID sample calculation. 


\section{Case Studies}

Three case studies are considered in this report. Each case study compares the total LCC of an electric chiller and a gas-engine chiller at two different U.S. locations. Results show that the location of an installation (i.e., the local energy rate structure) has critical impact on the feasibility of the gas chillers.

\section{Small Capacity Chillers (less than 50 tons)}

Two chillers are considered in this case study. One is an electric chiller and the other is a gas chiller. Specifications for both chillers are shown in Table 6. Two different locations were chosen for the study: Fort Stewart, GA, and Fort Polk, LA. Table 7 shows the energy charges for both locations.

Based on the information shown in Tables 6 and 7 and the LCCID input/Excel ${ }^{\circledR}$ spreadsheet files (Figures 2 and 3) for the electric and gas-engine chillers, the LCCID provided the results for Fort Stewart shown in Figure 4.

In the case of Fort Polk, the same approach was taken giving the results shown in Figure 5.

Table 6. Small capacity chiller specifications.

\begin{tabular}{|l|c|c|c|c|}
\hline Chiller Type & $\begin{array}{c}\text { Chiller Capacity } \\
\text { (tons) }\end{array}$ & Efficiency & $\begin{array}{c}\text { Equipment Cost } \\
\text { (\$/ton) }\end{array}$ & $\begin{array}{c}\text { Installed Cost } \\
\text { (\$/ton) }\end{array}$ \\
\hline Electric & 40 & $1.1 \mathrm{~kW} /$ Ton & 668 & 1,300 \\
\hline Gas Engine & 40 & COP $=0.95$ & 1,000 & 2,000 \\
\hline
\end{tabular}

Table 7. Electric and gas rates for Fort Stewart and Fort Polk.

\begin{tabular}{|l|c|c|c|}
\hline Location & $\begin{array}{c}\text { Electricity (Weighted-Average) } \\
\text { Energy Charges } \\
\text { (\$/kW-hr) }\end{array}$ & $\begin{array}{c}\text { Electricity Demand Charges } \\
\text { (On-Peak) } \\
(\mathbf{\$ / k W})\end{array}$ & $\begin{array}{c}\text { Gas Charges } \\
(\mathbf{\$} / \text { therm) }\end{array}$ \\
\hline Fort Stewart, GA ${ }^{2}$ & 0.066 & 14.15 & 0.34 \\
\hline Fort Polk, LA & 0.029 & 2.87 & 0.49 \\
\hline 1 Based on 50\% on-peak usage & \\
2 Based on Georgia Power Company Schedule, Reference [6] \\
3 Gas rate based on Duke Energy Schedule, Reference [6]
\end{tabular}




\begin{tabular}{|c|c|c|c|}
\hline \multicolumn{4}{|c|}{ User Input: } \\
\hline \multirow{8}{*}{$\begin{array}{l}\text { User's } \\
\text { Input: }\end{array}$} & $\begin{array}{c}\text { Equipment Information: } \\
\text { Electric Chiller: }\end{array}$ & & \\
\hline & Capacity $=$ & 40 & Tons \\
\hline & Annual Operating Hours $=$ & 4000 & Hours \\
\hline & Efficiency of Electric Chiller $=$ & 1.10 & $\mathrm{~kW} / \mathrm{Ton}$ \\
\hline & Installed Unit Cost $=$ & 1300 & $\$ /$ Ton \\
\hline & Percentage of time On-Peak $=$ & $50 \%$ & \\
\hline & Energy Cost Information: & & \\
\hline & Electricity Energy Charges: & & \\
\hline \multirow{6}{*}{ LCCID Input } & ON-Peak $=$ & 0.1035 & $\$ / \mathrm{kWh}$ \\
\hline & OFF-Peak $=$ & 0.0275 & $\$ / \mathrm{kWh}$ \\
\hline & $\begin{array}{l}\text { Weighted-Average Electricity } \\
\text { Energy Charge (Calculated) }=\end{array}$ & 0.0655 & $\$ / \mathrm{kWh}$ \\
\hline & Electricity Demand Charges: & & \\
\hline & Annualized Demand Charge $=$ & 89.8 & $\$ / \mathrm{kW}-\mathrm{yr}$ \\
\hline & Period of Study: & & \\
\hline \multirow[t]{2}{*}{ LCCID Input } & Study Life $=$ & 20 & years \\
\hline & Calculations: & & \\
\hline \multirow[t]{3}{*}{ LCCID Input } & \begin{tabular}{|r|} 
Installed Cost $=$ \\
\end{tabular} & $\$ \quad 52,000$ & \\
\hline & On-Peak Electric Energy per year $=$ & 88.00 & MWh \\
\hline & Off-Peak Electric Energy per year $=$ & 88.00 & MWh \\
\hline LCCID Input & Total Electric Energy per year $=$ & 176.00 & MWh \\
\hline \multirow[t]{2}{*}{ LCCID Input } & Electricity Demand Cost per year $=$ & $\$ \quad 3,951.20$ & \\
\hline & Electricity Demand per year $=$ & $44,000.00$ & MW \\
\hline LCCID Input & Maintenance Cost $=$ & $\$ \quad 520.00$ & $1 \%$ of capital cost per year \\
\hline
\end{tabular}

Figure 2. LCCID input/Excel ${ }^{\circledR}$ spreadsheet file for electric chiller (Fort Stewart).

\begin{tabular}{|c|c|c|c|}
\hline \multicolumn{4}{|c|}{ User Input: } \\
\hline \multirow{7}{*}{$\begin{array}{l}\text { User's } \\
\text { Input: }\end{array}$} & Equipment Information: & & \\
\hline & Gas-Engine Chiller: & & \\
\hline & Capacity $=$ & 40 & Tons \\
\hline & Annual Operating Hours $=$ & 4000 & Hours \\
\hline & Efficiency of Gas-Engine Chiller $=$ & 0.95 & $\mathrm{COP}$ \\
\hline & Installed Unit Cost $=$ & 2000 & $\$ /$ Ton \\
\hline & Energy Cost Information: & & \\
\hline \multirow{3}{*}{ LCCID Input } & Gas Energy Charges: & & \\
\hline & Natural Gas cost $=$ & 0.34 & $\$ /$ thm \\
\hline & Period of Study: & & \\
\hline \multirow[t]{2}{*}{ LCCID Input } & Study Life $=$ & 20 & years \\
\hline & Calculations: & & \\
\hline \multirow[t]{3}{*}{ LCCID Input } & Installed Cost $=$ & $\$ 80,000$ & \\
\hline & Gas Energy Cost per year $=$ & $\$ 6,869.23$ & \\
\hline & Gas Energy per year $=$ & $20,203.63$ & Therms \\
\hline \multirow{3}{*}{$\begin{array}{l}\text { LCCID Input } \\
\text { LCCID Input } \\
\text { LCCID Input }\end{array}$} & Gas Energy per year $=$ & $2,020.36$ & M-Btu \\
\hline & $\begin{array}{r}\text { Replacement Cost of Gas-Engine } \\
\text { every } 5 \text { years }=\end{array}$ & $16,000.00$ & $20 \%$ of capital cost every 5 years \\
\hline & Maintenance Cost $=$ & $\$ 2,400.00$ & $3 \%$ of capital cost per year \\
\hline
\end{tabular}

Figure 3. LCCID input/Excel ${ }^{\circledR}$ spreadsheet file for gas-engine chiller (Fort Stewart). 


\section{梀 WinLCCID}

File É dit Reports Qpptions Window $\underline{\text { Help }}$

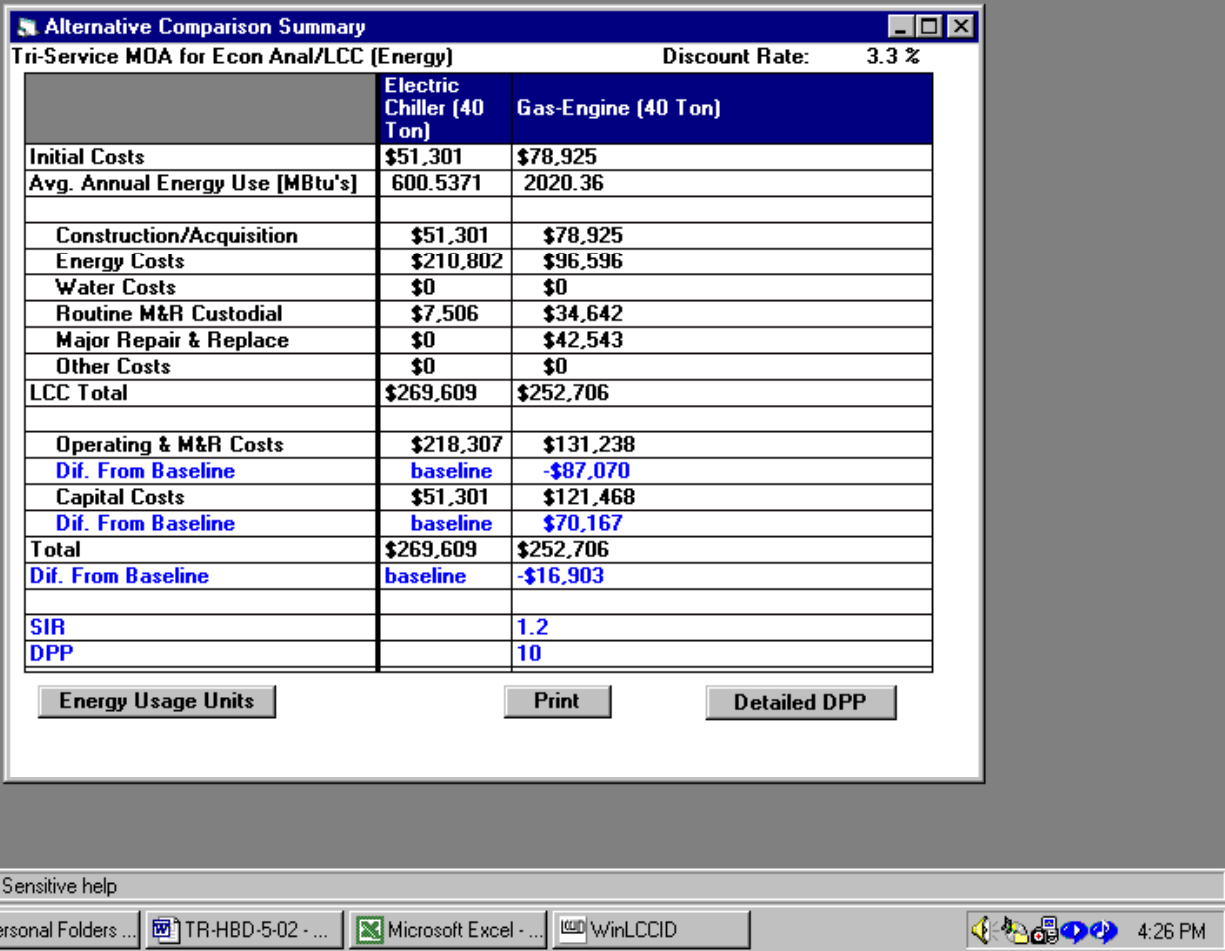

Use F1 for Context Sensitive

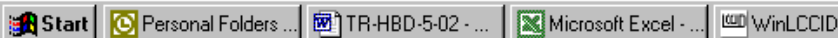

$26 \mathrm{PM}$

Figure 4. LCCID results for Fort Stewart, GA (40 ton).

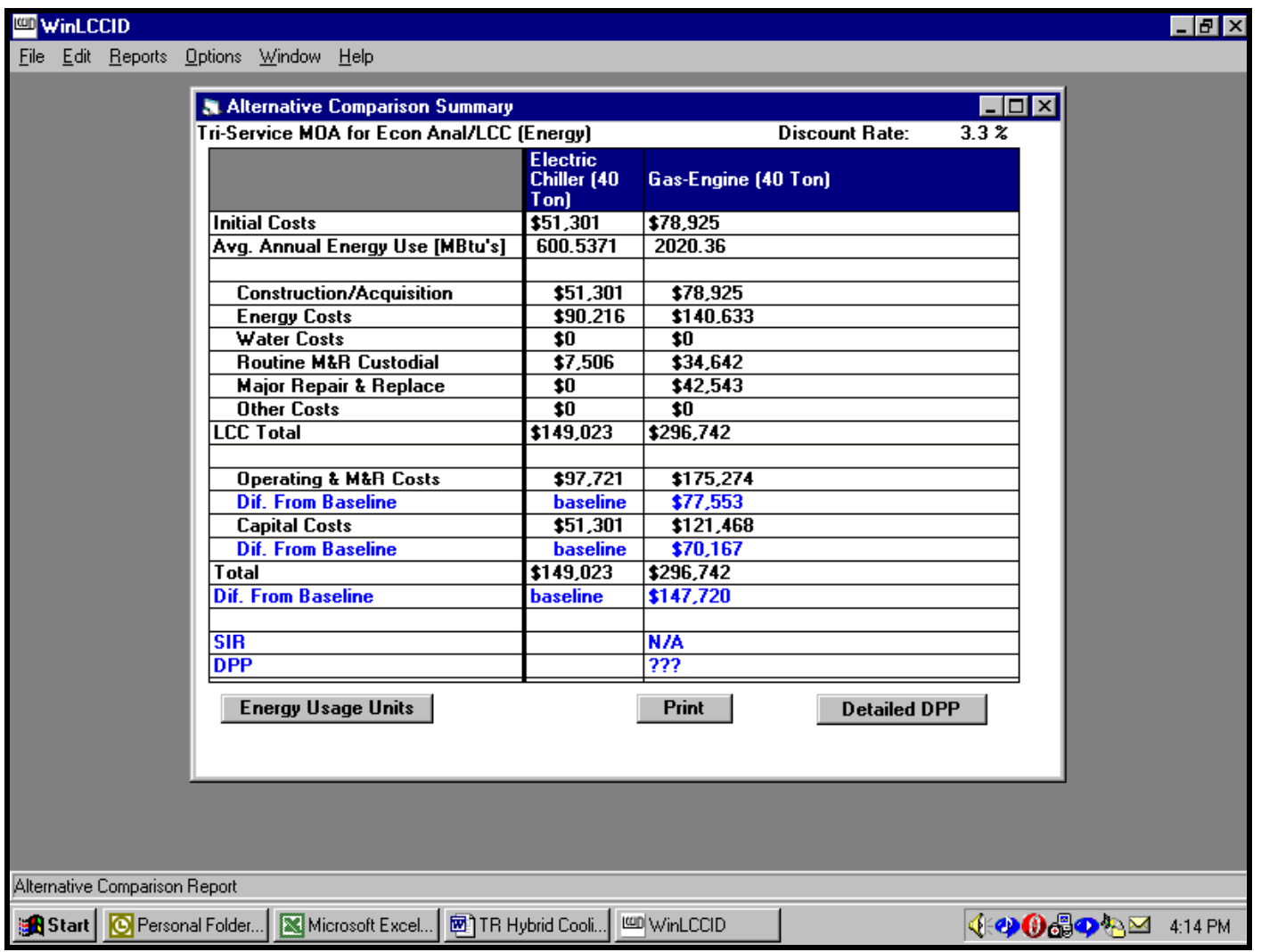

Figure 5. LCCID results for Fort Polk, LA (40 ton). 
As shown in Figures 4 and 5, a 40-ton electric chiller is the best option in Fort Polk but not necessarily in Fort Stewart when total LCC are compared. Differences in rate structure and pricing makes one option better than the other even when the same two chillers are chosen for the analysis. It can be observed that, although the gas-engine chiller consumes more energy, it is more economical when the gas rate is comparatively cheaper than the electricity rate. Its competitive advantage disappears, however, when the electricity rate is less expensive than the gas rate.

It is important to note that maintenance costs vary. It is assumed that, for a gas engine, maintenance costs are 3 percent of the installed cost and, for an electric chiller, only 1 percent (electric chillers require less maintenance). Also, gas engines need to be replaced every 5 years due to wear and aging. This engine replacement represents 20 percent of the installed cost every 5 years.

\section{Intermediate Capacity Chillers (50 - 200 tons)}

Two intermediate size chillers are considered in this case study. Specifications for both chillers are shown in Table 8 .

Based on the same energy rates, and Tables 7 and 8, LCCID provides the following results for Fort Stewart and Fort Polk, respectively (Figures 6 and 7).

As in the previous case study, a 150-ton electric chiller is the best option for Fort Polk by a large margin (as shown in Figure 7). However, the electric chiller is slightly better than the gas chiller at Fort Stewart (Figure 6). Again, differences in rate structure and pricing make one option better than the other even when the same two chillers are chosen for the analysis. In this case study, however, an electric chiller is simply a better alternative for both locations even under the most favorable circumstances for the gas-engine chiller (low gas rate and high electricity rates).

Table 8. Intermediate capacity chiller.

\begin{tabular}{|l|c|c|c|c|}
\hline Chiller Type & $\begin{array}{c}\text { Chiller Capacity } \\
\text { (tons) }\end{array}$ & Efficiency & $\begin{array}{c}\text { Equipment Cost } \\
\text { (\$/ton) }\end{array}$ & $\begin{array}{c}\text { Installed Cost } \\
\text { (\$/ton) }\end{array}$ \\
\hline Electric & 150 & $0.64 \mathrm{~kW} /$ Ton & 352 & 1,000 \\
\hline Gas Engine & 150 & $\mathrm{COP}=1.5$ & 500 & 1,500 \\
\hline
\end{tabular}




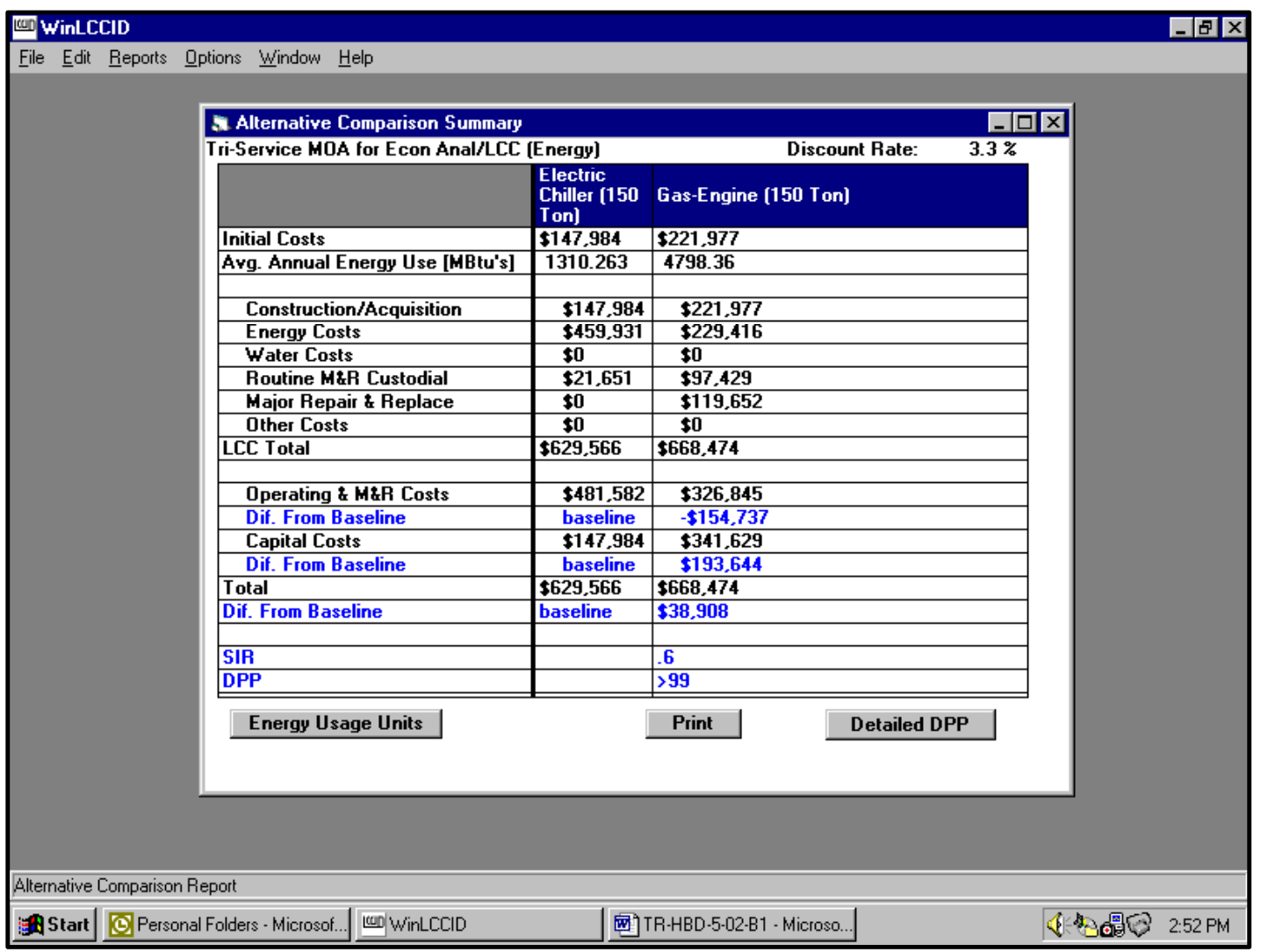

Figure 6. LCCID results for Fort Stewart, GA (150 ton).

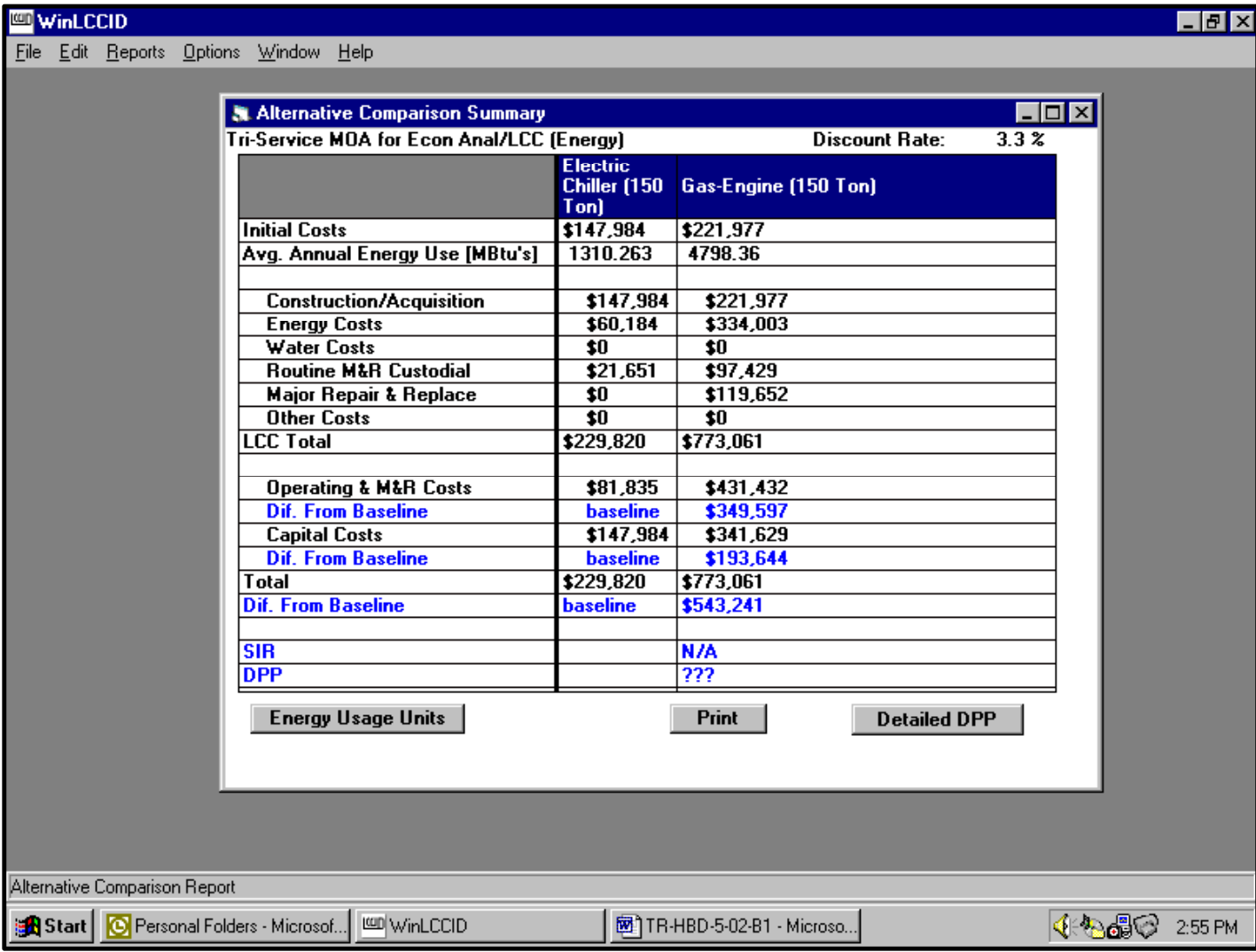

Figure 7. LCCID results for Fort Polk, LA (150 ton). 


\section{Large Capacity Chillers (more than 200 tons)}

Two 600-ton chillers are considered in this case study. Specifications for both chillers are shown in Table 9.

Based on the energy rates shown in Table 7, the chiller specifications, Table 9, LCCID provides the following results for Fort Stewart and Fort Polk respectively (Figures 8 and 9).

As in the first case study, a 600-ton electric chiller is the most cost effective and most economical option for Fort Polk by a large margin as shown in Figure 9. As shown in Figure 8, however, a gas-engine chiller is a better option than the electric chiller at Fort Stewart due to high electricity rates.

Table 9. Large capacity chiller.

\begin{tabular}{|l|c|c|c|c|}
\hline Chiller Type & $\begin{array}{c}\text { Chiller Capacity } \\
\text { (tons) }\end{array}$ & Efficiency & $\begin{array}{c}\text { Equipment Cost, } \\
\text { (\$/ton) }\end{array}$ & $\begin{array}{c}\text { Installed Cost } \\
\text { (\$/Ton) }\end{array}$ \\
\hline Electric & 600 & $0.56 \mathrm{~kW} / T o n$ & 293 & 800 \\
\hline Gas Engine & 600 & COP $=1.92$ & 500 & 1,000 \\
\hline
\end{tabular}

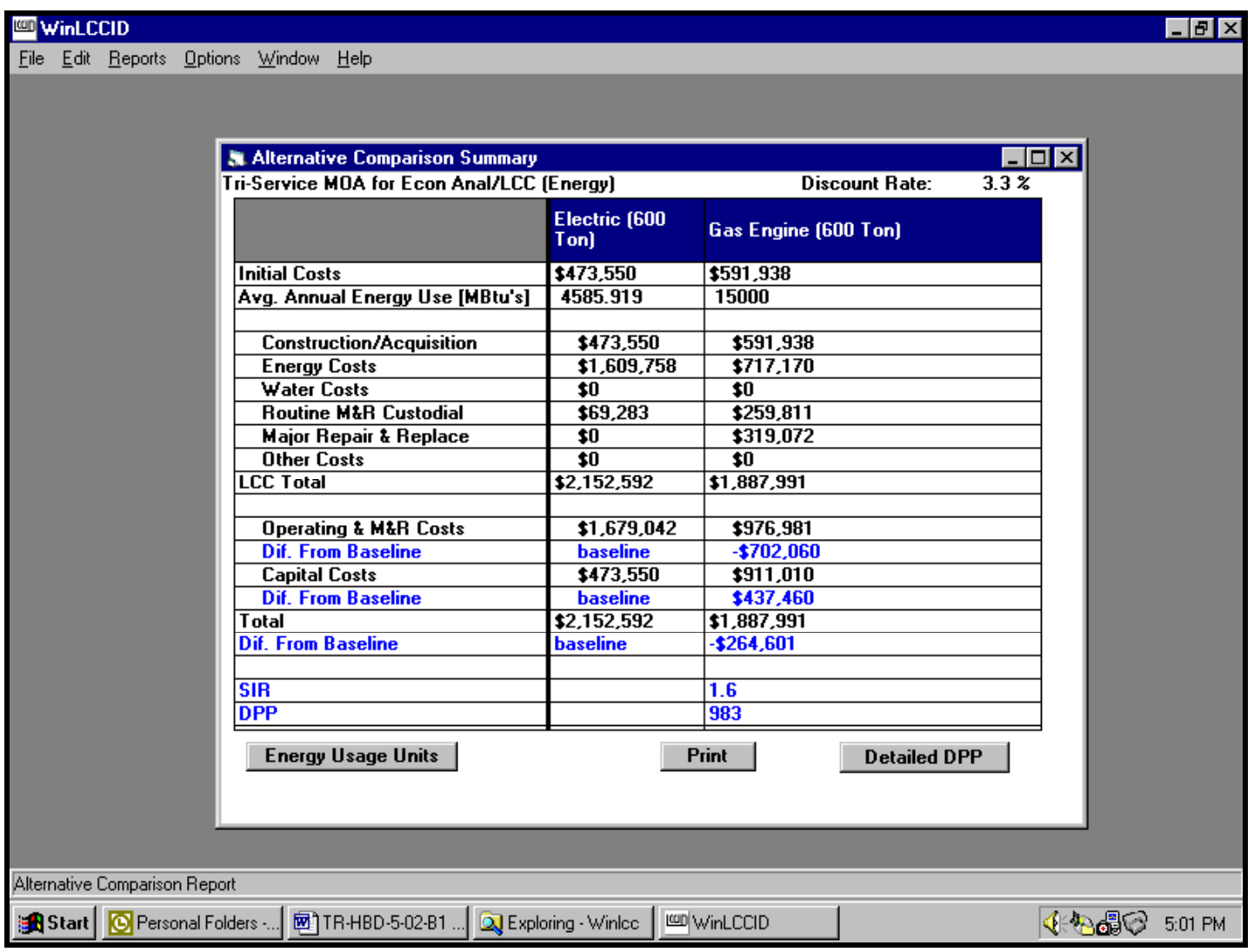

Figure 8. LCCID results for Fort Stewart, GA (600 ton). 


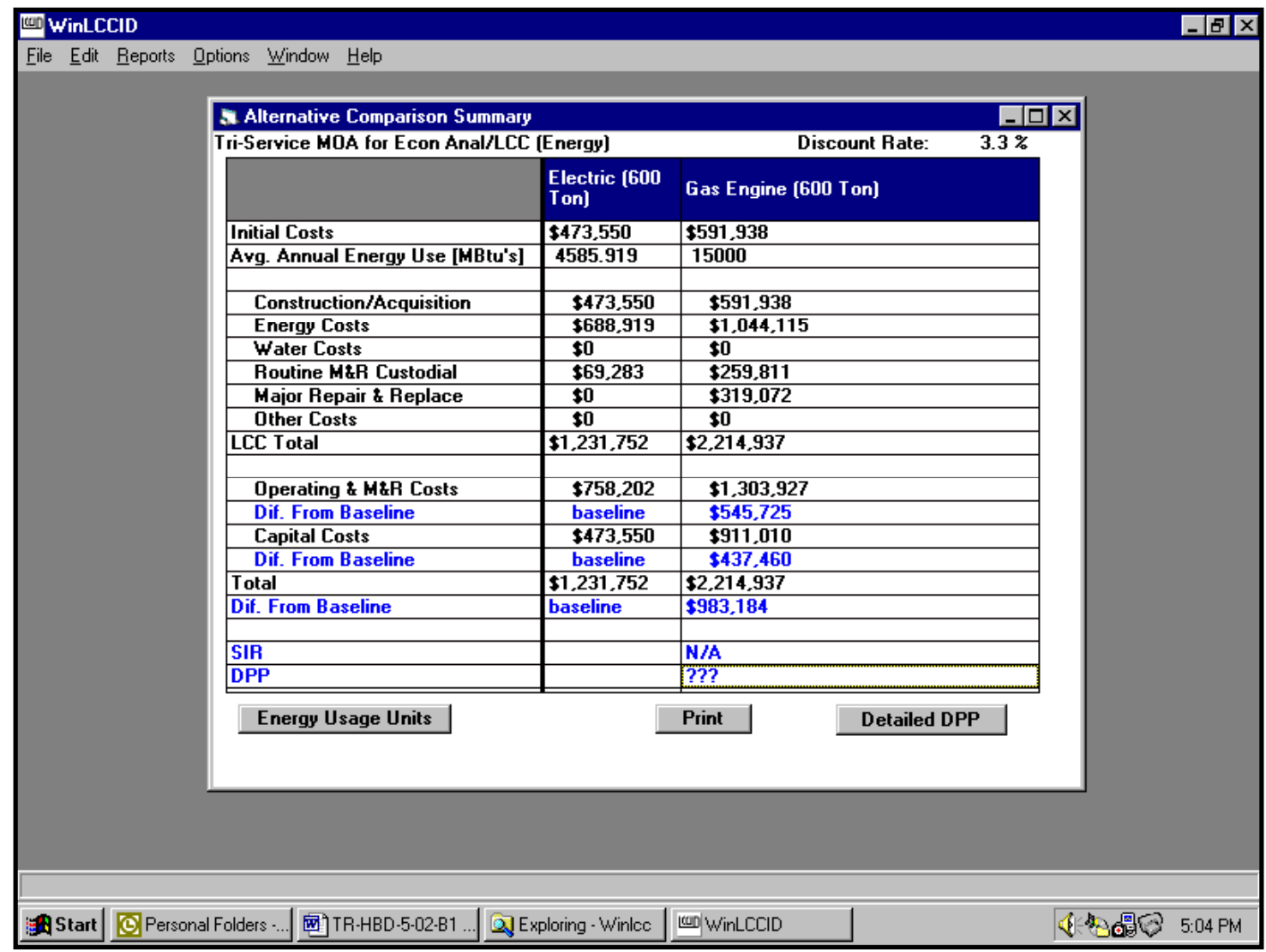

Figure 9. LCCID results for Fort Polk, LA (600 ton).

\section{Simplified Limiting Criteria}

A theoretical LCC model is developed with assumptions of constant rates in the annual fuel cost escalation, the annual maintenance cost, and the discount rate. The model is as follows:

$\mathrm{C}_{\mathrm{e}}=$ electric chiller first cost in $\$ /$ ton (installed)

$\mathrm{C}_{g}=$ natural gas chiller first cost in $\$ /$ ton (installed)

$c_{e}=$ electricity cost in $\$ / k W h$ (including the demand portion)

$\mathrm{c}_{g}=$ natural gas cost in $\$$ /therm (including the demand portion)

$\mathrm{m}_{\mathrm{e}}=$ electric chiller annual maintenance cost in $\$ / \mathrm{ton} / \mathrm{yr}$

$m_{g}=$ natural gas chiller annual maintenance cost in $\$ /$ ton/yr

$f_{e}=$ fraction of capital cost for annual maintenance cost (electrical) 


$$
\begin{aligned}
& f_{g}=\text { fraction of capital cost for annual maintenance cost (natural gas) } \\
& H=\text { number of chiller operating hours in a year }(\mathrm{h} / \mathrm{yr}) \\
& \mathrm{e}_{\mathrm{e}}=\text { efficiency of electrical chiller in } \mathrm{kW} / \mathrm{ton} \\
& e_{g}=\text { efficiency of natural gas chiller in COP } \\
& r_{e}=\text { annual electricity cost escalation rate }(\% / \mathrm{yr}) \\
& r_{g}=\text { annual natural gas cost escalation rate }(\% / \mathrm{yr}) \\
& r_{d}=\text { discount rate }(\% / y r) \\
& N=\text { study life }(y r) \\
& \text { LCC }_{e}=\text { total life cycle cost }(\$ / \text { ton, electric chiller }) \\
& \text { LCC }_{g}=\text { total life cycle cost }(\$ / \text { ton, natural gas chiller })
\end{aligned}
$$

With routine algebraic manipulation,

$$
\begin{aligned}
& \operatorname{LCC}_{e}=\mathrm{C}_{e}+N f_{e} C_{e}+e_{e} C_{e} H\left[\frac{1-\left(\frac{1+r_{e}}{1+r_{d}}\right)^{N}}{\frac{r_{d}-r_{e}}{1+r_{d}}}\right] \quad \text { when } r_{d} \neq r_{e} \quad \text { Eq } 1 \\
& \mathrm{LCC}_{\mathrm{e}}=\mathrm{C}_{\mathrm{e}}\left(1+\mathrm{Nf}_{\mathrm{e}}\right)+\mathrm{e}_{\mathrm{e}} \mathrm{C}_{\mathrm{e}} \mathrm{NH} \quad \text { when } \mathrm{r}_{\mathrm{d}}=\mathrm{r}_{\mathrm{e}} \quad \text { Eq } 2
\end{aligned}
$$

and

$$
\begin{aligned}
& \mathrm{LCC}_{g}=\mathrm{C}_{g}+\mathrm{Nf}_{g} \mathrm{C}_{g}+\left(\frac{0.12 \mathrm{HC}_{g}}{\mathrm{e}_{\mathrm{g}}}\right)\left[\frac{1-\left(\frac{1+\mathrm{r}_{g}}{1+\mathrm{r}_{d}}\right)^{\mathrm{N}}}{\frac{\mathrm{r}_{\mathrm{d}}-\mathrm{r}_{\mathrm{g}}}{1+\mathrm{r}_{\mathrm{d}}}}\right] \\
& \mathrm{LCC}_{\mathrm{g}}=\mathrm{C}_{\mathrm{g}}\left(1+\mathrm{Nf}_{\mathrm{g}}\right)+\mathrm{C}_{\mathrm{g}}\left(\frac{0.12}{\mathrm{e}_{\mathrm{g}}}\right) \mathrm{NH} \quad \text { when } \mathrm{r}_{\mathrm{d}}=\mathrm{r}_{\mathrm{g}} \quad \text { Eq } 4
\end{aligned}
$$


In the above analysis, the annual escalation rate of the maintenance cost was assumed to be equal to the discount rate. Note that Equations 1 and 2 are the basis of the LCCID software. In LCCID the fuel cost escalation rates (for electricity and natural gas) are specified per CONUS region (Department of Energy [DOE] regions) and future time intervals (e.g., every year), and those numbers are updated every year. The official discount rate is also specified in the LCCID program.

DELTA is defined here as the difference in LCC between an electric chiller and a gas chiller. In the case of $r_{d}=r_{e}=r_{g}$ (i.e., same escalation rates for future cost of electricity and natural gas, and discount rate), the analysis is reduced to the simple payback analysis that does not take into account future inflation and discount. In this case, DELTA is arrived at from Equations 2 and 4, with a few algebraic manipulations,

$$
\begin{array}{ll}
\text { DELTA }=C_{e}\left(1+N f_{e}\right)+c_{e} e_{e} N H-C_{g}\left(1+N f_{g}\right)+C_{g}\left(\frac{0.12}{e_{g}}\right) N H & \text { Eq } 5 \\
\text { DELTA }=\left(C_{e}-C_{g}\right)\left(1+N f_{g}\right)+N C_{e}\left(f_{e}-f_{g}\right)+N H\left(C_{e} e_{e}-\frac{0.12 c_{g}}{e_{g}}\right) \quad \text { Eq } 6
\end{array}
$$

If DELTA in Equation 5 is positive, the LCC of the electric chiller is higher and a gas chiller is preferred, and vice versa. The first term in Equation 5 represents the effect of the first cost differential between electric and gas chillers; the second term, the effect of the annual maintenance cost differential; and the last term, the effect of energy cost (electricity or gas) differential on the LCC difference between the electric and gas chillers. The first term (first cost differential) will always be less than zero (due to the higher cost of a natural gas engine compared with an electric motor). The second term will also be less than zero (due to the higher maintenance cost of the gas engine compared with an electric motor), and the magnitude of the last term will depend mainly on the energy cost differential between electricity and natural gas.

A limiting case is when a value of the last term in Equation 5 becomes less than zero. In that case, DELTA will always be less than zero, the LCC of the electric chiller will be less than that of the natural gas chiller, and the choice should be the electric chiller. It is the limiting criterion that disqualifies the natural gas chiller from further consideration. The value of the last term in Equation 5 is defined here as D. 


$$
D=N H\left(c_{e} e_{e}-\frac{0.12 c_{g}}{e_{g}}\right)
$$

For typical values of $\mathrm{e}_{e}$ and $\mathrm{e}_{g}$ (efficiency of chillers) in the current market, $\mathrm{e}_{e}=0.5$ $\mathrm{kW} /$ ton and $\mathrm{e}_{g}=1.5$. Insert these values in Equation 6,

$$
D=N H\left(0.5 c_{e}-0.08 c_{g}\right)
$$

For the value of $\mathrm{D}$ to be positive, the value of $0.5 \mathrm{c}_{e}$ must be larger than that of $0.08 \mathrm{c} g$. Therefore, the limiting criterion, $\mathrm{Y}$, of the energy cost differential is,

$$
\begin{aligned}
& Y=\frac{0.5 c_{e}}{0.08 c_{g}} \\
& Y=\frac{c_{e}}{0.16 c_{g}}>1 \\
& c_{g}<6.25 c_{e}
\end{aligned}
$$

The conclusion from the inequality in Equation 9 is that the cost of natural gas, $\mathrm{c} g$ in $\$ /$ therm, cannot be greater than six and one-quarter times the cost of electricity, $c_{e}$ in $\$ / \mathrm{kWh}$, for a gas chiller to be competitive. As an example, if the cost of electricity (including the demand portion) is $\$ 0.05 / \mathrm{kWh}$, the available gas rate must be less than $\$ 0.3125 /$ therm for a gas chiller to be considered. 


\section{Discussion}

\section{Sensitivity Analysis}

The feasibility of gas chillers depends on the electric and gas rate structures as shown by the LCCID results in Chapter 3. As with most of the feasibility studies, the input values of the first cost (i.e., installed unit cost) and the annual recurring cost (i.e., annual electricity/gas and maintenance costs) have critical impact on the calculation of the total LCC. These costs, unfortunately, are not easily obtainable and fluctuate rather significantly under ongoing electric deregulation and a deregulated natural gas market.

A sensitivity analysis was conducted to estimate the impact of these fluctuating cost conditions. Using the section in Chapter 3 on "Large Capacity Chillers" and the results for Fort Stewart as a baseline, three cases were studied. Case 1 is based on the same conditions as the baseline except for the increased annual maintenance cost (from 3 to 5 percent) for the natural gas chiller. Case 2 is the same as the baseline except for a 20 percent reduction in electricity cost. Case 3 is the same as the baseline except for a 20 percent reduction in natural gas cost. Table 10 summarizes the total LCC for these cases.

Results in Table 10 show that a slight change in the input variable can tilt the LCCbased chiller selection in either direction. Note also that the input variables (chiller installed cost, annual maintenance cost, future electricity and natural gas costs in the next 20 years) for the natural gas chillers are neither firmly established in the current market nor accurately predictable for the next 20 years. Therefore, a sensitivity study is strongly recommended unless a significant LCC cost differential (e.g., more than 25 percent) is shown during the early selection stage.

Table 10. Total life cycle cost for a 600-ton chiller.

\begin{tabular}{|l|c|c|}
\hline & Electric chiller & Natural gas chiller \\
\hline Baseline & $\$ 2,152,592$ & $\$ 1,887,991$ \\
\hline Case 1 & $\$ 2,152,592$ & $\$ 2,061,199$ \\
\hline Case 2 & $\$ 1,829,938$ & $\$ 1,887,991$ \\
\hline Case 3 & $\$ 2,152,592$ & $\$ 1,170,821$ \\
\hline
\end{tabular}




\section{Discussion}

In light of recent national events, the equipment selection process needs to address security and reliability concerns for military installations in addition to more traditional criteria such as the LCC of a chiller. In terms of security, the natural gaselectric hybrid chiller systems do not present additional security requirements compared to conventional electric chillers. As for reliability issues, the hybrid systems can provide additional benefit as a diversified fuel source (i.e., electricity and natural gas). The natural gas chiller only, however, has less reliability than an electric chiller. The reduced reliability is due to the maintenance of an additional component (natural gas engine) and the limited service infrastructure to maintain the gas cooling chillers. Interest from a number of major gas chiller manufacturers has been waning during the last several years. Interest of the traditional electric utility industries in managing their on-peak problems with the gas cooling technology has been diluted during the ongoing electric deregulation process. The gas-chiller-only option, therefore, might adversely impact the reliability of cooling service at this time.

The economic benefit of the gas chiller has been documented in field operations (Brown 1998). Its benefit on a life-cycle basis requires consideration of the chiller installed cost, annual maintenance cost, and the annual fuel cost savings. These issues are discussed on the basis of a theoretical model, Equation 5a.

$$
\operatorname{DELTA}=\left(C_{e}-C_{g}\right)\left(1+N f_{g}\right)+N C_{e}\left(f_{e}-f_{g}\right)+N H\left(c_{e} e_{e}-\frac{0.12 c_{g}}{e_{g}}\right)
$$

The DELTA in Equation 5a is the LCC difference between the electric and the gas chiller. The fuel cost advantage of the gas chiller in the third term has to be compared with the additional first cost, the first term, and the additional maintenance cost shown in the second term. Typically the installed cost of a gas chiller is higher than that of an electric chiller. If an incentive program is available to compensate the installed cost differential, as in the 1990s before electric deregulation began, DELTA will become positive, and the gas chiller will be an economical alternative to the electric chiller.

A quick decision tool for the economic feasibility of a gas chiller is given in Equation 9 .

$$
c_{g}<6.25 c_{e}
$$


Again, $c_{g}$ and $c_{e}$ are the costs of natural gas and electricity (including the demand contribution) in $\$ /$ therm and $\$ / \mathrm{kWh}$, respectively. Note that determining electricity cost is not a simple process such as reading it from a utility bill. One indirect method would be to divide a summer month's cost in dollars by the total kilowatthours consumed during the same billing period for which the monthly cost in dollars is determined. If utility rates at a candidate installation do not satisfy the inequality (Equation 9), gas cooling should not be considered as an alternative to electric cooling. If any gas cooling incentive is provided, DELTA in Equation 5 should be calculated next. If DELTA turns out to be positive, a detailed LCCID analysis should be performed before the final decision is made. 


\section{Conclusion}

Generally speaking, a single gas chiller is not recommended to provide cooling due to maintenance and reliability concerns. A gas chiller as part of an electric-natural gas hybrid cooling plant merits consideration due to the potential savings in fuel costs.

A decision model and supporting tools are summarized in Figure 10. The symbols and units are given in the Chapter 3 section on Simplified Limiting Criterion.

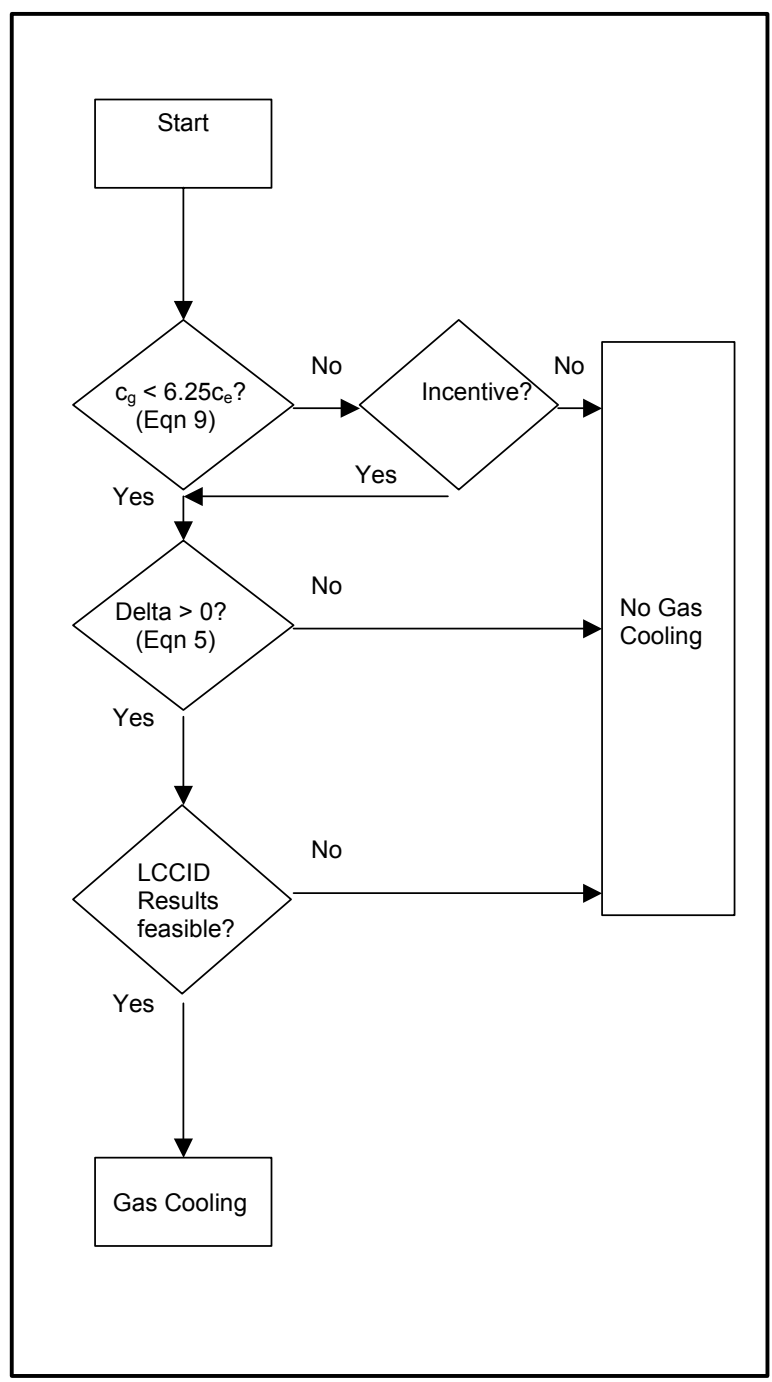

Figure 10. Chiller selection decision model. 


\section{References}

Akbari, H. and S. Konopacki, End-Use Energy Characterization and Conservation Potentials at DOD Facilities: An Analysis of Electricity Use at Fort Hood, Texas, LBL-36974 UC-000 (Lawrence Berkeley Laboratory, May 1995).

Brown, W.T., Performance Analysis of Natural Gas Cooling Technology at Air Force Bases, ERDC/CERL TR-99-14/ADA359312 (Construction Engineering Research Laboratory [CERL], December 1998).

Electric Power Research Institute (EPRI), EPRI Electric Chiller Handbook, TR-105951-R1 (EPRI, February 1998).

Feickert, C.A. and C.W. Sohn, Electrical and Natural Gas Rates for Cooling in Major Army Installations, ERDC/CERL TR-00-25/ADA382337 (CERL, August 2000).

Liegois, W., "CHILLER Prime Movers," HPAC Heating/Piping/Air-Conditioning Engineering (March 2000), pp 55-62.

Meckler, M., "Real-Time Savings,” Consulting-Specifying Engineer (July 1999), pp 49-53.

Nowakowski, G. and M. Gramlich, "New Developments in Hybrid Natural Gas/Electric Cooling," ASHRAE Journal (September 1999), pp 36-42.

Sohn, C.W., W.T. Brown, R.E. Rundus, T.W. Pedersen, T.E. Durbin, M.A. Caponegro, D. Matsui, Natural Gas Cooling in DoD Facilities, USACERL Technical Report 97/125/ADA332974 (U.S. Army CERL, August 1997). 


\section{CERL Distribution}

Chief of Engineers

ATTN: CEHEC-IM-LH (2)

Assistant Chief of Staff for Installation Management

ATTN: DAIM-FDF-VE

Engineer Research and Development Center (Libraries)

ATTN: ERDC, Vicksburg, MS

ATTN: Cold Regions Research, Hanover, $\mathrm{NH}$

ATTN: Topographic Engineering Center, Alexandria, VA

Commander, Fort Bragg, NC 28307-5000

ATTN: Directorate of Public Works

Commander, Fort Buchanan, PR 00934-5040

ATTN: Directorate of Public Works

Commander, Fort Campbell, KY 42223 ATTN: PWBC

Commander, Fort Carson, CO 80913-5023

ATTN: Directorate of Public Works

Commander, Fort Drum, NY 13602-5097

ATTN: Directorate of Public Works

Commander, Fort Hood, TX 76544-5057

ATTN: Directorate of Public Works

Commander, Fort Irwin, CA 92310-5097

ATTN: Directorate of Public Works

Commander, Fort Lewis, WA 98433-9500

ATTN: Directorate of Public Works

Commander, Fort McPherson, GA 30330-1018

ATTN: Directorate of Installation Support

Commander, Fort Polk, LA 71459-5440

ATTN: Directorate of Installation Support

Commander, Fort Riley, KS 66442-6016

ATTN: Directorate of Public Works

Commander, Fort Stewart, GA 31314-41928

ATTN: Directorate of Public Works
Commander, Fort Benning, GA 31905-5122

ATTN: Directorate of Public Works

Commander, Fort Bliss, TX 79916-6816

ATTN: Directorate of Public Works

Commander, Fort Carlisle, PA 17013-5059

ATTN: Directorate of Public Works

Commander, Fort Chaffee, AR 72905-1370

ATTN: Facilities \& Engineering

Commander, Fort Eustis, VA 23604-5306

ATTN: Directorate of Public Works

Commander, Fort Gordon, GA 30905-5040

ATTN: Public Works Division

Commander, Fort Huachuca, AZ 85613-6000

ATTN: Public Works Division

Commander, Fort Jackson, SC 29207-5650

ATTN: Public Works Division

Commander, Fort Knox, KY 40121-5000

ATTN: Directorate of Public Works

Commander, Fort Leavenworth, KS 66027-1360

ATTN: Directorate of Public Works

Commander, Fort Lee, VA 23801-5200

ATTN: Directorate of Public Works

Commander, Fort Leonard Wood, MO 65473-8944

ATTN: Directorate of Public Works

Commander, Fort McClellan, AL 36205-5000

ATTN: Directorate of Public Works

Commander, Fort Monroe, VA 23651-6000

ATTN: Directorate of Public Works

Commander, Fort Rucker, AL 36362-5140

ATTN: Directorate of Public Works

Commander, Fort Sill, OK 73503-5100

ATTN: Directorate of Public Works

Defense Tech Info Center 22304

ATTN: DTIC-O

34

$5 / 02$ 


\begin{tabular}{|c|c|c|}
\hline $\begin{array}{l}\text { 1. REPORT DATE (DD-MM-YYYY) } \\
07-2002\end{array}$ & 2. REPORT TYPE & 3. DATES COVERED (From - To) \\
\hline \multirow{3}{*}{\multicolumn{2}{|c|}{$\begin{array}{l}\text { 4. TITLE AND SUBTITLE } \\
\text { Natural Gas-Electric Hybrid Cooling System for Army Facilities }\end{array}$}} & 5a. CONTRACT NUMBER \\
\hline & & 5b. GRANT NUMBER \\
\hline & & 5c. PROGRAM ELEMENT NUMBER \\
\hline \multirow{3}{*}{\multicolumn{2}{|c|}{$\begin{array}{l}\text { 6. AUTHOR(S) } \\
\text { Chang W. Sohn and Jorge L. Alvarado }\end{array}$}} & $\begin{array}{l}\text { 5d. PROJECT NUMBER } \\
\text { 622784AT45 }\end{array}$ \\
\hline & & $\begin{array}{l}\text { 5e. TASK NUMBER } \\
\text { CF }\end{array}$ \\
\hline & & $\begin{array}{l}\text { 5f. WORK UNIT NUMBER } \\
\text { X60 }\end{array}$ \\
\hline \multicolumn{2}{|c|}{$\begin{array}{l}\text { 7. PERFORMING ORGANIZATION NAME(S) AND ADDRESS(ES) } \\
\text { U.S. Army Engineer Research and Development Center (ERDC) } \\
\text { Construction Engineering Research Laboratory (CERL) } \\
\text { PO Box } 9005 \\
\text { Champaign, IL } 61826-9005\end{array}$} & $\begin{array}{l}\text { 8. PERFORMING ORGANIZATION REPORT } \\
\text { NUMBER } \\
\text { ERDC/CERL TR-02-15 }\end{array}$ \\
\hline \multirow{2}{*}{\multicolumn{2}{|c|}{$\begin{array}{l}\text { 9. SPONSORING / MONITORING AGENCY NAME(S) AND ADDRESS(ES) } \\
\text { Headquarters, U.S. Army Corps of Engineers (HQUSACE) } \\
441 \text { G Street, NW. } \\
\text { Washington, DC 20314-1000 }\end{array}$}} & 10. SPONSOR/MONITOR'S ACRONYM(S) \\
\hline & & $\begin{array}{l}\text { 11. SPONSOR/MONITOR'S REPORT } \\
\text { NUMBER(S) }\end{array}$ \\
\hline
\end{tabular}

12. DISTRIBUTION / AVAILABILITY STATEMENT

Approved for public release; distribution is unlimited.

\section{SUPPLEMENTARY NOTES}

Copies are available from the National Technical Information Service, 5285 Port Royal Road, Springfield, VA 22161.

\section{ABSTRACT}

Operation of space cooling equipment accounts for more than half of the annual peak electrical demand and a third of the total electrical energy consumed in a typical Army installation. As a means to reduce the peak electrical demand in kilowatts and electrical energy consumption in kilowatt-hours, a number of Army installations installed natural gas engine chillers during the 1990s through Congressional appropriations, the Federal Energy Management Program (FEMP), and installation operations and maintenance (O\&M) funds.

This report reviews field performance of these systems and provides a selection guide for cooling systems in the Army installations. Life-cycle cost analysis of chillers in three ranges of cooling capacity was conducted to determine the economical benefit of hybrid cooling systems. The capacity ranges are: less than 50 tons, 50-200 tons, and greater than 200 tons, which correspond to typical small administration buildings, barracks or large office buildings, and central cooling plant applications, respectively. The study results

show that the electric-gas hybrid cooling system is recommended only when a favorable fuel cost rate is available for natural gas compared to electricity.

\section{SUBJECT TERMS}

cooling systems energy conservation

16. SECURITY CLASSIFICATION OF:

a. REPORT

Unclassified b. ABSTRACT Unclassified hybrid cooling systems

life-cycle cost (LCC)

c. THIS PAGE

Unclassified

\begin{tabular}{|c|c|}
$\begin{array}{l}\text { 17. LIMITATION } \\
\text { OF ABSTRACT }\end{array}$ & $\begin{array}{c}\text { 18. NUMBER } \\
\text { OF PAGES }\end{array}$ \\
SAR & 32
\end{tabular}

